\title{
Research on Governance Behavior and Inheritance Performance: A Review Based on Chinese Family Businesses
}

\author{
Mengyun $\mathrm{Wu}^{1} \&$ Lei $\mathrm{Pan}^{1}$ \\ ${ }^{1}$ School of Finance \& Economics, Jiangsu University, Zhenjiang, China \\ Correspondence: Mengyun Wu, School of Finance \& Economics, Jiangsu University, Zhenjiang, China. E-mail: \\ mewu@ujs.edu.cn
}

Received: May 12, 2012 Accepted: June 20, 2012 Online Published: September 20, 2012

doi:10.5539/ass.v8n12p148 URL: http://dx.doi.org/10.5539/ass.v8n12p148

This research is supported by National Natural Science Fund (71102160), Humanities and Social Sciences Project of Ministry of Education (10YJC630281), National Statistics Fund(2011LY053), Philosophy \& Social Science Project of Jiangsu Province (09SJB630014\&2010SJB630014) \& Advanced Talent Project of Jiangsu University (09JDG050)

\begin{abstract}
Governance behavior is a symbol of institutions and mechanisms which is used for standardizing variable relationships between families and businesses. The family businesses' effective inheritance and sustainable development have unavoidably become two of the biggest challenges for family businesses and owners in the fortune-accumulating process. The paper explains the contents of two types of governance, both relational governance and contractual governance of family business, as well as inheritance performance, discusses the complicated dimension and structure of enterprises' performance, such as family business' performance, family success and the working attitudes of staff members. The paper also discusses the relationship between contractual governance and family businesses' inheritance, and the relationship between relational governance and family businesses' inheritance.
\end{abstract}

Keywords: governance behavior, inheritance performance, family success

\section{Governance Behaviour and Family Business Governance}

Economists have given various explanations of relevant corporations' governance behaviour. Reviewing on different kinds of viewpoints, Mayer and Hart (1997) believe that businesses' governance problems will arise from enterprises' organizations. Thus, family governance is an indispensable and institutional arrangement of family businesses for averting the hazards concerning agents.

\subsection{Two Types of Governance: Relational Governance and Contractual Governance of Family Business}

Contractual governance means governing a transaction through formal contracts. For example, structures like board meetings and board of supervisors, systems used for encouraging the colleagues, contracts linking corporations and stakeholders, etc. The risks are the requirements for contractual governance in the market transactions (Williamson, 1985; Klein, Crawford, Alchian, 1978). Owing to the investments on specific purposes and asymmetric information, professional managers probably make use of their operational and managerial power in pursuit of personal interests more than businesses' overall interests. In order to lower the transactional risks between family businesses and professional managers, the family businesses will surely reinforce contractual governance as the power to regulating enterprises and professional managers (Mustakallio, 2002; Su Qi and Li Xin Chun, 2004).

Relational governance is to govern transactions through relational norms. Relational norms refer to some social processes and regulations which exist because of the counterparts' relations in a transaction (Baker, Gibbons and Murphy, 2002). McNeal (1978) held the view that contracts can be explained as the exchange relations among different persons. Every exchange has two features: contractual and relational. In fact, there are many scholars engaged in the management study on relational contracts' governance and taking assts' specificity put forward in the Game Theory and relational norms into consideration. For instance, Zaheer and Venkatraman (2002) believe that relational contracts' governance consists of structure and process. The relational structure dimension is 
represented as vertical semi-integration while processes underlined in the relationship and presented as joint actions. Assets' specificity, uncertainty and mutual-beneficial investments as well as trust have all played important roles as engine in affecting the structures and processes of relational contracts' governance. In spite of experiential study insufficient supporting their assumptions, it is innovative to have equal emphasis on all these factors and has profound influences on relational contracts' research. Through experiential study, Claro (2003) discovered joint actions' extents (including joint plans and resolutions) of strategic allied enterprises are affected by transactional forms, investments on the labour capital in the transactions, businesses' network density and trust between organizations and persons. The four factors as mentioned above have influence on the joint plans while only personal trust and trust between organizations together affect the extent of problems' joint resolution (Claro, Hagelaar and Omta, 2003).

\subsection{Relationship between Relational Governance and Contractual Governance}

There have existed big disputes about the functions and mutual influences between relational governance and formal contracts. One viewpoint is that formal contracts and relational governance are complementary (Gulati, 1995; Dyer And Singh, 1998). Another viewpoint is that relational governance and formal contracts are supplementary. Accurately designed formal contracts won't impede or replace relational governance, in fact, will improve credible long-term coordinative and transactional relationship. Poppo and Zenger (2004) have proved by empirical study that relational governance and formal contracts have complementary relations. They have discovered that combining formal and informal measures together will emerge a better transactional performance than just choosing one measure alone. Clear procedures of contractual clauses, contract amendments and contradiction resolution, together with elastic, bilateral and sustainable relational governance will fulfil relational contracts more smoothly. Thus, the governance approaches of relational contracts should be made up of large number of methods.

\section{Research on Family Businesses' Inheritance Performance}

\subsection{Enterprises' Performance: Complicated Dimension and Structure}

Enterprises' performance is sometimes called the organizations' performance, as is illustrated in the book Industrial/Organizational Psychology, which is written by Seal and Knight (1988). Venkatraman and Ramanujam (1989) pointed out that an enterprise's performance is of multi-dimensional structures and has three levels: firstly, financial performance like ROA, ROS, ROE, etc.; secondly, business performance which is based on assessing quota of the market; thirdly, organizations' performance which is made up of 2 layers closely relevant to quality and social responsibility. Murphy (1990) believes that performance is a group of behaviours linked with organizations where people work or organizational units' targets. Borman and Motowidlo (1993) put forward two-dimensional models of performance which supports the view that behaviours' performance consists of task performance and relation performance while Bates and Holton conducted researches in three terms as organizations, groups and individuals. Lu Xin Fan, Li Huang Zhao and Hart (1997) evaluated enterprises' performance at the standpoint of strategy. In spite of different points of views and focuses, we inevitably place more emphasis on financial performance, and to some extent neglect management systems' organizational behaviours especially organizational culture.

\subsection{Family Businesses' Performance: A Realistic Choice According to the Measurement}

In reviewing the literature, family involvement is an important feature of family businesses, the strength and weakness of family involvement are the key elements of determining a family business' performance. Family involvement affects the family businesses' performance through families' goals, relationships and resources. We can apply Agent Theory and Resource-oriented Theory to analyze and assess the influence on family businesses' performance. In general, factors relating to families will have a positive influence on family businesses' performance. In the long run, an important question make people confused is that whether the data is credible and has a relatively good reflection of businesses' performance (Kunkel and Hofer, 1993).

\subsection{Concept of Inheritance Performance}

Scholars tend to prefer the study of enterprises' systematic achievements than researches on family businesses' sustainable development. Devine (2003) has discovered that the less standardized enterprises' organizations will generate less income, and there are studies showed that home-based businesses generate less income than non-home-based businesses. Wood (1996) added environmental latitude into factors determining businesses' success. Olson (1994) has found that family businesses located in rural areas tend to come across cash-flow problems in contrast to those located in urban areas. Some scholars put forward that family businesses' sustainable development include not only businesses' success but also families' success(Olson, 1994; 
Habersham, 1998), they also have the idea that the family businesses' sustainable growth necessarily need strong support of businesses' inheritance performance. Thus, Sorenson \& Olson (2003) have gradually formed the SFB (family business sustainability) model, which attribute family business' inheritance performance to the function of enterprises' and families' performance.

\section{Research on Inheritance Performance: A Review Base on Governance Behaviour}

Fama \& Jenson (1984) believe that the stock shares of family businesses are governed by family members. Family members have special personal relationship with decision-making agents; also family members have greater competitive edge over others in supervising and constraining agents. McConaughy (2000) has conducted study on operational efficiency when initiators and the family members becomes CEO. The results have exposed that those enterprises which has a CEO of initiator or a family member have a higher operational efficiency than enterprises which have recruited CEO from outside. Li Xinchun \& Chen Can (2005) confirmed through empirical research that the selection of family businesses' governance model will have a direct effect on businesses' inheritance performance. Mustakallio (2002) \& Filatotchev (2005) conducted some studies on family businesses' governance models' influences upon enterprises performance, illustrated and listed as Figure 1.

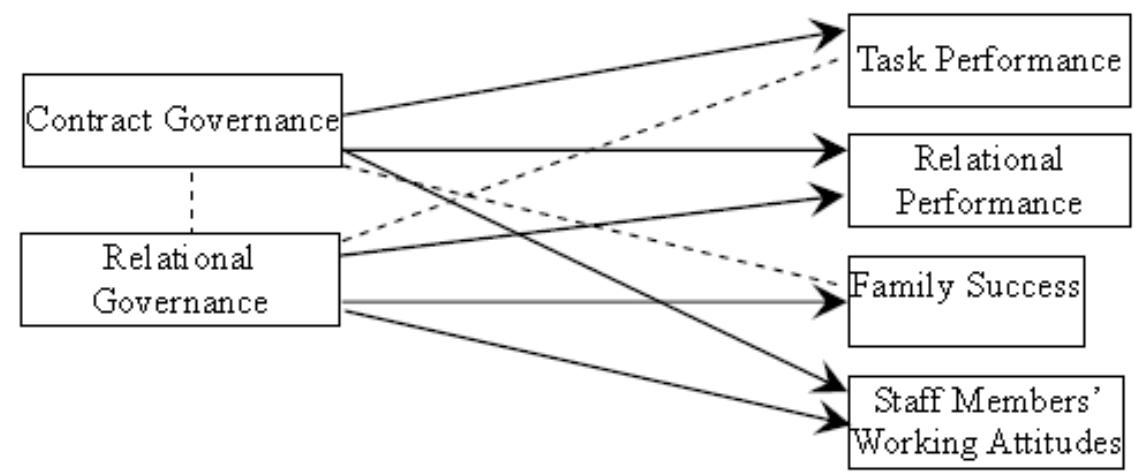

Figure 1. Relationship between governance structure and performance of family enterprises

\subsection{Contractual Governance and Family Businesses' Inheritance Performance}

Contractual governance affects the starting point of enterprises' performance. Enterprises' ownership and governance structures determine the features of attaining resources from internal and external markets: The structure of property rights of enterprises directly affects the ability of raising fund from capital market. In China, the approaches of family businesses to applying for a program fund are very limited, not only because of its complicated procedures, but also because of the capital's enactment with the genuine need of enterprises. In the magazine Fortune, Mizruchi \& Stearns(1994)'s research on 22 family businesses among 400 enterprises shows that the financial representatives of the board meetings are relevant to businesses' debts, and the type of the board meeting's financial representatives directly affects the type of financial mechanisms that businesses use and businesses' performance. The models of enterprises' governance also have extensive impact on the characteristics of their human resources. Nowadays, due to relatively undeveloped external market systems of our nation, family businesses tend to select and foster elites needed from internal environment. As the ever-increasing development of manager market, enterprises are enabled to employ MBA (master of business administration) and professional managers who have received formal education. These two different talents' sources surely have different influence on enterprises' performance. The models of enterprises' governance affect and limit managers' decision-making power. Different ownership structures contribute to different autonomous limitations of authority managers possess, and they both directly affect managerial strategy and performance. The board meetings act as a mechanism to reduce enterprises' environmental uncertainty. The different sources of chairmen enable themselves to play an important role as a bumper and a coordinator in the boundaries and link essential resources in the environment and organizations with valuable information existed in chairman interlock network (Price, 1963; Zald, 1969; Pfeifer, 1972). The interlock network of chairman has both adverse and favourable influence on information attainment. The good effects of the chairman interlock are that it can connect and make full use of information within the coverage of interlock network, and the bad effects are that it will easily constrain the information exchange among businesses within the interlock network.

Fama \& Jensen (1983) believed that the stock share of family businesses is in the charge of family members. Family members have an especially personal relationship with decision-making agents and more merits in 
supervising and restraining agents. Chrisman conducted comparative analysis on agency cost of family and non-family businesses by introducing controlling mechanism of agency cost, obtained conclusion that family businesses do better in reducing agency cost. William (1993) analyzed incentive mechanism's influence on family and non-family member's, manifested the fact that altruistic behaviors and mutual faith enable family members to gain the ability of self-constraining. Although family businesses' interior contractual governance seems to cool the families' relationship, visible contracts are more advanced than invisible patriarchal clan system which is concealed in the families (Lee, 1996). The family it self's features changing with the time. Contractual governance model which is based on agency theory not only contributes to the subtle changes of families' values and concepts but also has more effective effects on safeguarding families' interests than businesses' interests. That is to say, the more completed one region's law is and the higher the law enforcement's efficiency is, the more confident people (including family members and enterprises' staff members) will be in the effectiveness of non- personified standardized contracts secured by law.

Robbins (1997) believed that working attitudes are the positive and negative comments of staff members in working environment and the attitudes closely relevant with the job. Working attitudes consist of cognition, affect and behavior. But in order to meet the need of simplification and practicality, it is often divided into two dimensions as organizational commitment and organizational citizenship behavior. In the practice of family businesses, it is a common convention to grant staff member's incentives such as vocational development opportunities practice according to their working performance and attitudes. In family businesses, staff members' contractual governance is a systematic project, requiring personnel department to take an all-around part in the organizational strategic management process, and to make plans for assuring staff members' skills, behaviors and attitudes supporting the strategic schemes. On the one hand, organizations can get much more benefits from governance performance brought in by more devoted and loyal staff members, on the other hand, staff members also can attain satisfaction from professions which are more challenging and have more variable contents (Stavrou, 1998).

\subsection{Relationship Governance and Family Businesses' Inheritance Performance}

Relationship is a capital which cannot be neglected by enterprises in modern society, called "Guan-xi Capital" or "Social Capital". The board of directors attains relational values through creating friendly relationship with stakeholders and making enterprise easily get access to stakeholders' resources supports from suppliers, sellers, customers, governments and social communities. Thus, it is helpful to create stable cash flows. And due to the strong relational characteristics of family businesses' themselves, relational governance, together with formal institutional or contractual arrangement, enable family businesses to share the same goals for both attorneys and trustees. As a result, it can achieve the goal of reducing agent cost, transactional risk and improving the enterprises' sustainability, furthermore, it can achieve the ultimate goal of enhancing financial performance (Sandra Waddock and Neil Smith, 2000).

According to previous researches, family businesses' relational governance contributes significantly to family success. Family success demonstrates valuations of family businesses' entrepreneurs and their family members on the quality of family lives (Retting and Leichtentritt, 1999). Obviously, such kind of relatively high relationship-governance model, which is dealing well with the relationship between family members and family businesses themselves, will definitely obtain high remarks from family businesses' entrepreneurs themselves or family members. That is to say, not only can family businesses reach tremendous success by restructuring the construct of relational governance model, but also entrepreneurs and their families.

In the 1970s, US psychologist Schoen put forward that due to the special relationships among contractors (such as family members), enterprises are always governed by such kind of relationship, and the basic measurement quotas consist of job satisfaction, job involvement and organizational commitment. In family businesses, relational contracts usually meet staffs members' job satisfaction and strong Sense of belonging to organizations through personnel resources governance. In spite of its invisible shape, relational governance plays an important role just like visible contracts. Rambled (1994) pointed out that in family businesses, the relationship between labor and capital tend to be built into the establishment of a cooperative, mutual-respected relationship and rational disputes' resolve between employers and employees, as is represented by harmonious relationship-governance models. English scholars Malay(1999), by conducting research on samples picked from 6000 random telephone interviews and 600 family businesses, discussed and analyzed the essence of family businesses' relationship between capital and labor. His conclusion was that the employers and managers of family businesses tend to adapt to informal relationship-governance models of family businesses. Enterprises are clearly aware of each staff member's demands and requirements for the future and satisfy staff members as far as employers can. However, staff members also devote themselves to the enterprises' development because they 
firmly believe that the enterprises can satisfy their demand and hope. And there are some scholars holding the view that as the entrepreneurs and their successors are always characterized by caring, mercy, fully faith, harmonious obligation and businesses' cultures, they have a remarkable influence on organizational commitment and organizational citizenship behaviors of staff members (Steers, 1977; Podsakoff, MacKenzie and Panie, 2000; Wang Chong Ming).

\section{Conclusions}

From the above, we can draw a conclusion that there are plenty of theories and models to expose family business inheritance. For example, explanations on the basis of classic 3-circle theory, family lives' cycle theory, and trustee-attorney theory, explanations of succession inheritance mechanism on the basis of the theories of stakeholders and behavioural science, etc. However, if we are keen to have a comprehensive and systematic understanding of family businesses' inheritance and inheritance performance, the studies nowadays is still not enough. At the same time, we can draw the conclusion from previous studies and the practice of family businesses' succession inheritance that family businesses' succession inheritance is often a long-term process including a series of processes coherent and mutually connected. Every procedure like children's access, successors' selection, undertaking important responsibilities step by step, the adjustment of governance models and effects evaluation after succession are all contents deserved to be studied.

Nowadays, in addition, we have found that although there are numerous qualitative and quantitative researches on family businesses, which is not only focus on the relationship between family businesses' succession inheritance and businesses' performance, but also focus on the relationship between family governance models and businesses' performance, the studies about family businesses' succession inheritance processes, family governance models, mutual forces and mechanisms of contractual and relational governance, and the complex structure of family businesses' sustainable performance are still scarce. Thus, undoubtedly, they will be interesting and valuable fields and orientations for the future study and worthy of scholars' further exploration.

\section{References}

Dyer, W. G., \& Sanchez, M. (1998). Current State of Family Business Theory and Practice as Reflected in Family Business Review 1988-1997. Family Business Review, 1(4), 287-295. http://dx.doi.org/10.1111/j.1741-6248.1998.00287.x

Faccio, M. (2002). The Ultimate Ownership of Western European Corportions. Fiancial Economics, (65), 365-395.

Hu, Junzhu, Wen, Sheng, \& Pang, Daoman. (2002). Laboral Contracts, Transactional Expense and Relational Governance-the Analysis of Family Businesses' Interior Governance Behavior in China. Beijing Jiaotong University (Scientific and Social Edition), (3), 35-42.

Klein, B. A., \& Crawford, A. (1987). Alch Vertical Integration, Appropriable Rents, and the Competitive Contracting process. Law and Economics, (6), 115-123.

Le Breton Miller, I., Miller, D., \& Steier, L. (2004). Towards an Integrative Model of Effective FOB Succession: $\begin{array}{lllll}\text { Entrepreneurship. Theory } & \text { and }\end{array}$ http://dx.doi.org/10.1111/j.1540-6520.2004.00047.x

Lee, D. S., Lim, G. H., \& Lim, W. S. (2003). Family business succession: appropriation risk and choice of successor. Academy of Management Review, 28(4), 657-666.

Li, Booming. (2009). The Study on Family Businesses's Leaders' Behaviors, Governance Models and Performance [In Chinese]. Economy and Science Press, China.

Ocasio, \& William (1999). Institutionalized Action and Corporate Governance: The Reliance on Rules of CEO Succession. Administrative Science Quarterly, 44(2), 384-416.

Olson, M. (2003). Dictatorship, Democracy, and Development. The American Political Science Review, 87(3), 567-576. http://dx.doi.org/10.2307/2938736

Poppo, L., \& Zenger, T. (2002). Do Formal Contracts and Relational Governance Function as Substitutes or Complements.

Redding, G. (1993). The Spirit of Chinese Capitalism (De Gruyter Studies in Organization). Shanghai: Shanghai Sanlian Bookstore.

Sharma, P. (2004). An overview of the field of family business studies: current status and directions for the future. Family Business Review, 17(1), 1-36. http://dx.doi.org/10.1111/j.1741-6248.2004.00001.x 
Sharma, P., Chrisman, J. J., \& Chua, J. H. (2003). Succession Planning As Planned Behavior: Some Empirical Results. Family Business Review, 16(1), 1-16. http://dx.doi.org/10.1111/j.1741-6248.2003.00001.x

Steier, L. (2001). Next Generation Entrepreneurs and Succession: An Exploratory Study of Modes and Means of Managing Social Capital. Family Business Review, 14(3), 259-276. http://dx.doi.org/10.1111/j.1741-6248.2001.00259.x

Su, Qi, \& Li, Xinchun. (2008). Family Business: Enterprises' Governance and Development. Beijing: Economy and Science Press.

Zhang, Yuhua. (2005). The Study on Family Businesses' Development Processes and Governance Models. Hunan: Central China University of Sciences and Technology Press. 